\title{
Research Paper \\ The Effectiveness of Training the Behavioral Management Flow Chart (BMFC) Program to Mothers on the Aggressive Behavior of Students with Oppositional Defiant Disorder
}

\author{
Roya Heidari*1, Pegah Azadimanesh ${ }^{2}$, Sedigheh Ranjbar Horoee ${ }^{3}$ \\ 1. M.A. of School Counseling, Faculty of Humanities \& Social Sciences, University of Kurdistan, Iran \\ 2. Ph.D. Student of General Psychology, Faculty of Literature and Humanities, University of Guilan, Rasht, Iran \\ 3. M.A. Student of Family Counseling, Kermanshah branch, Islamic Azad University, Kermanshah, Iran
}

Citation: Heidari R, Azadimanesh P, Ranjbar Horoee S. The effectiveness of training the behavioral management flow chart (bmfc) program to mothers on the aggressive behavior of students with oppositional defiant disorder. Quarterly Journal of Child Mental Health. 2019; 6(3): 101111.

http://dx.doi.org/10.29252/jcmh.6.3.10

\section{A R T I C L E I N F O}

\section{Keywords:}

Behavioral management flow chart, aggressive behavior, oppositional defiant disorder

Received: 5 Dec 2018

Accepted: 15 Apr 2019

Available: 9 Nov 2019

\section{A B S T R A C T}

Background and Purpose: Oppositional behavior is the most frequent reason for which parents refer to the health centers. Symptoms of these problems appear in childhood and preschool period and if not being treated they continue and lead to long-term outcomes, including school dropouts and personality disorders. The purpose of this study was to investigate the effectiveness of training behavioral management flow chart program to mothers on the aggressive behavior of students with oppositional defiant disorder.

Method: The present study was a semi-experimental study with pretest- posttest control group design with two-month follow-up period. The study population was composed of mothers of 7-9 year-old male students in Kermanshah in academic year 2017-2018. Thirty mothers, whose children were diagnosed with oppositional defiant disorder based on Child Behavior Checklist (Achenbach, 2001) and Child Symptom Inventory (Gadow \& Sprafkin, 1994), were selected by convenience sampling. The mothers were randomly assigned to either the experimental or the control group (15 per group). Then, the experimental group received behavioral management flow chart program in 8 sessions of 90 minutes. For data analysis, split-plot ANOVA design (SPANOVA)was used.

Results: Findings showed that behavioral management flow chart program had a significant effect on the aggressive behavior $(\mathrm{F}=29.21, \mathrm{P}<0.01)$ and these results remained stable during the twomonth follow-up.

Conclusion: Based on the findings of the present study, it can be concluded behavioral management flow chart program without the use of strict punitive methods can lead to the decrease of aggressive behaviors in children with oppositional defiant disorder.

\footnotetext{
* Corresponding author: Roya Heidari, M.A. of School Counseling, Faculty of Humanities \& Social Sciences, University of Kurdistan, Iran.

E-mail addresses: Roya9285h@gmail.com
} 


\section{اثربخشى آموزش برنامه روندنماى مديريت رفتار به مادران بر رفتار يرخاشكر انه دانش آموزان مبتلا به اختلال نافرمانى مقابلهاى}

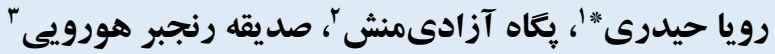

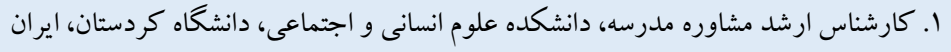

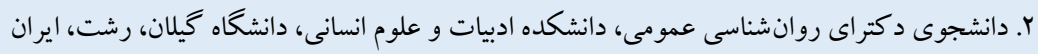

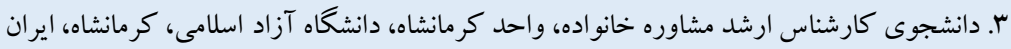

\section{جكيده}

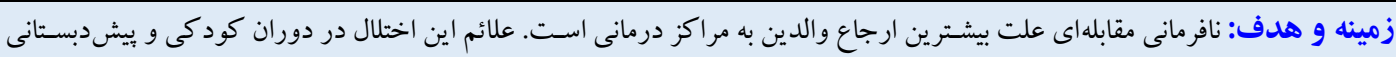

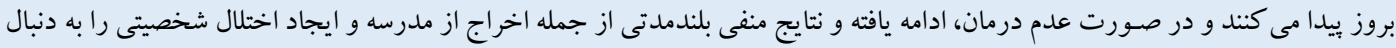

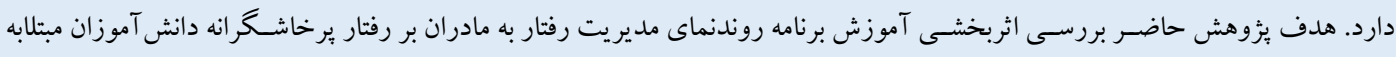
اختلال نافرمانى مقابلهاى بود.

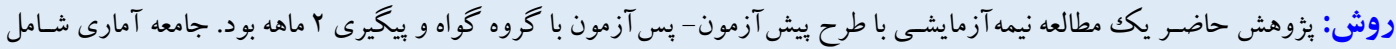

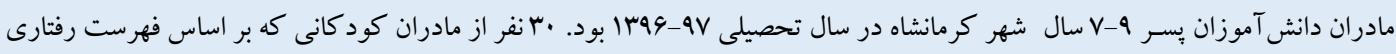

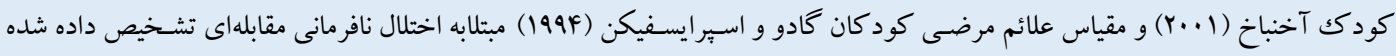

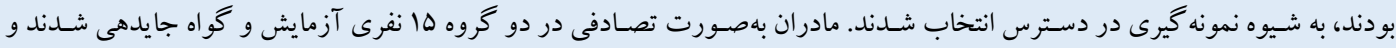

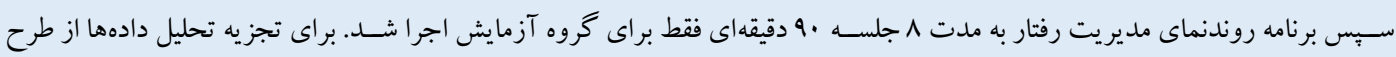
تحليل واريانس مختلط با اندازهيرى مكرر استفاده شد.

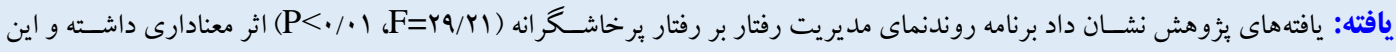
نتايج در دوره بيخيرى دوماهه نيز بايدار بود.

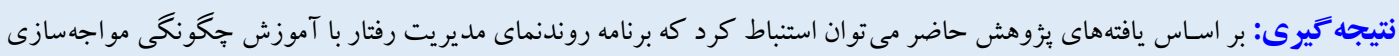

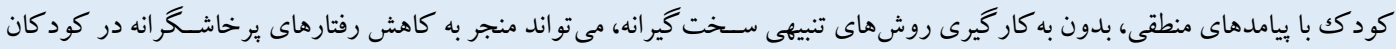

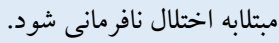

مشخصات مقاله

كليدوازهها: برنامه روندنماى مديريت رفتار، رفتار بر خاشكر انه،

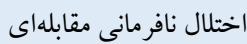

دريافت شده:

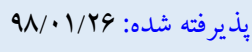

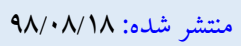

* نويسنده مسئول: رويا حيدرى، كارشناس ارشد مشاوره مدرسه، دانشكده علوم انسانى و اجتماعى، دانشكاه كردستان، ايران.

راياناه: Roya9285h@gmail.com

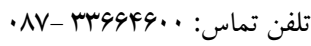


توجـه بيشازحســ بـه رفتـارهاى مقابلهاى كود كانشــان، ميزان وقوع

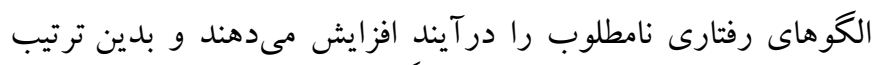

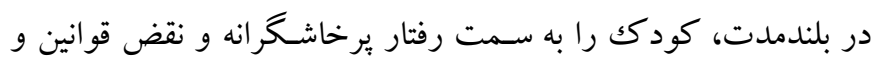

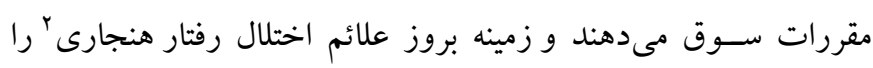

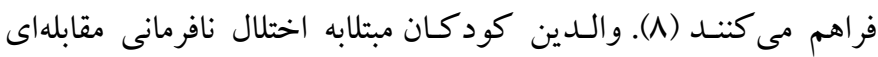

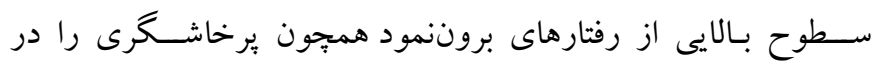

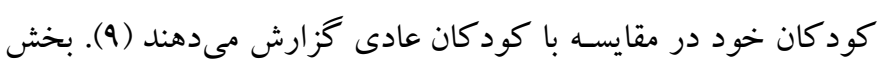

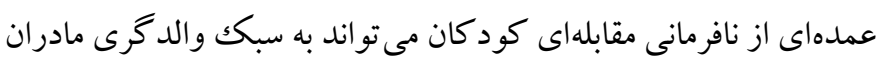

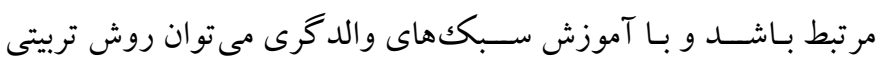

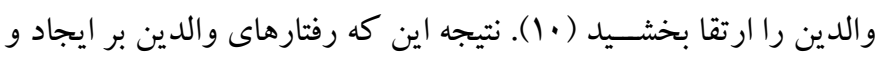

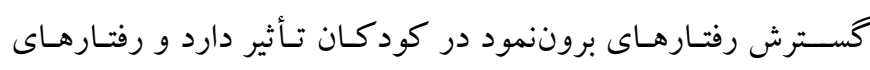

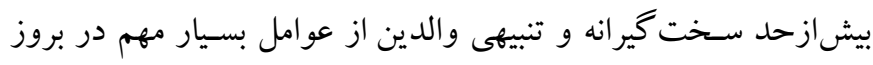

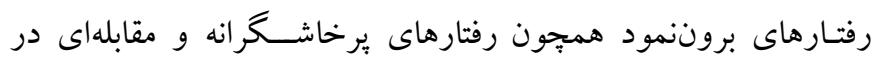

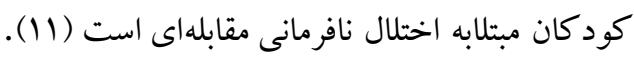
تاكنون نظريههاى بسيارى به بررسى سببشناسى و درمان اختلال

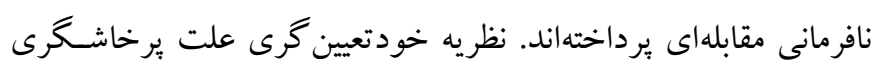

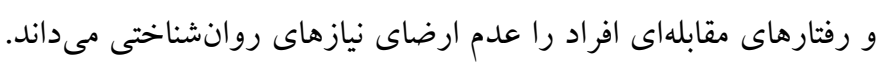

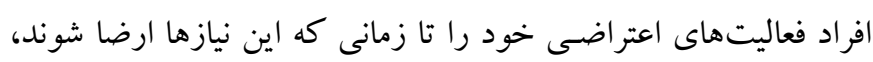

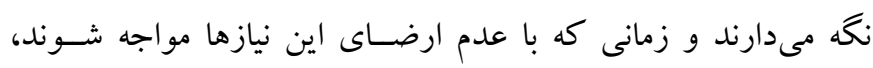

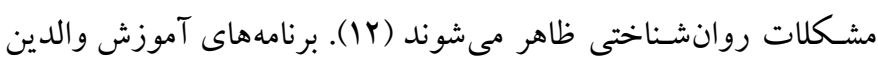

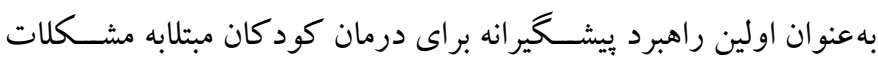

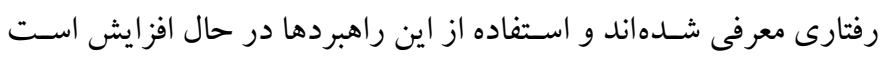

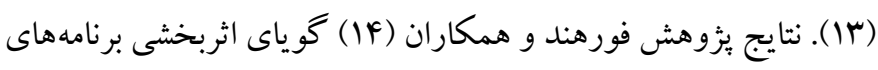
آموزش والـدين بر مشــكلـات رفتـارى كود كان اســت. نتايج فراتحليل

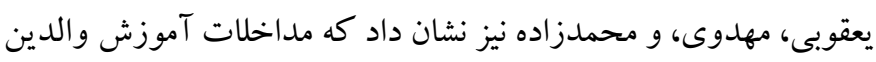

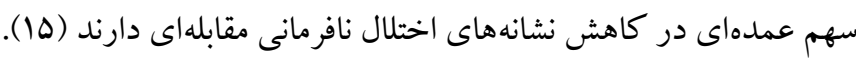
نتايج بزوهش خدابخش و جعفرى (19) نشان داد كه آموزش والدين

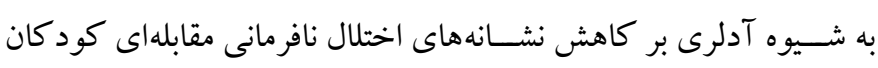
مؤثر بوده است. قدرتى مير كوهى، شريفى در آمدى و عبداللهى بقر آبادى ندي

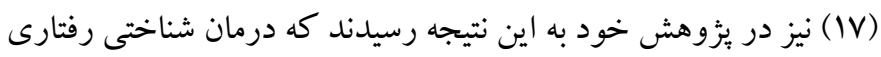

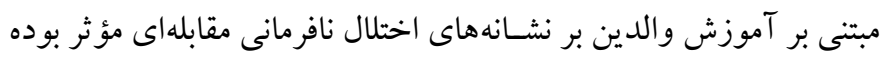

2. Conduct disorder
مقلهم اختلال نـافرمانى مقـابلـهاى' الكوى بـايـدار منفى كـارى، نـافرمـانى، لجبـازى،

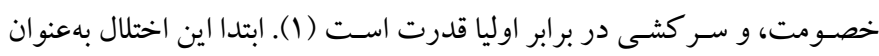

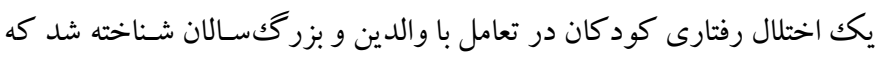

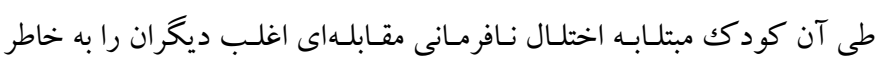
اشـتباهات و ســوء رفتارهاى خودش مقصــر مى داند (Y). ميز ان شــيوع اختلال

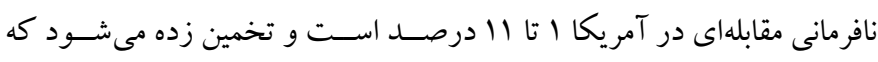

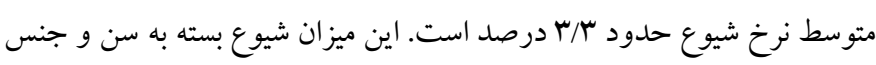

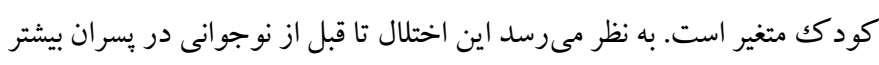
از دختران است (ץ). يكلى از بيشترين علت هاى ارجاع والدين به مراكز درمانى، مشكلات

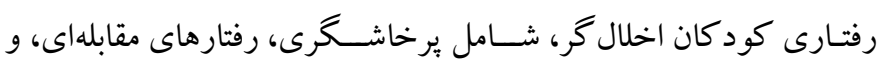

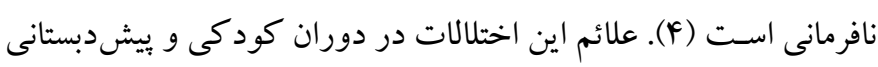

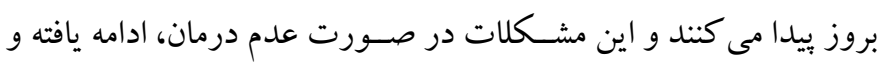

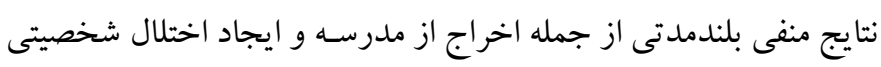

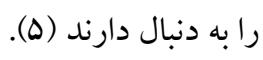

اختلال نافرمانى مقابلهاى تقريباً هميشه در روابط بين فردى و عملكرد

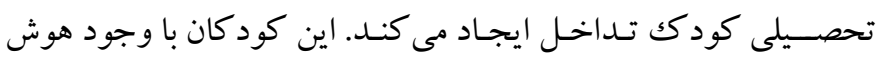

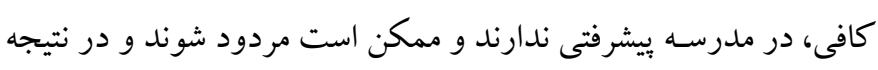

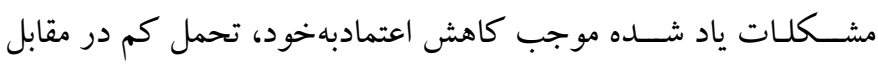

كامنايافتكىها، روحيه افسرده، و حملات كجخلقى مى ئود (4).

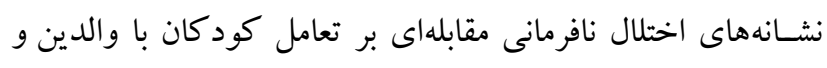

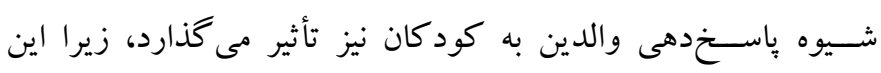

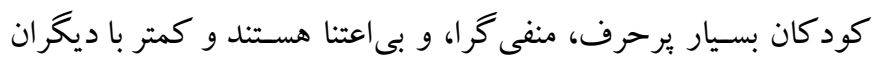

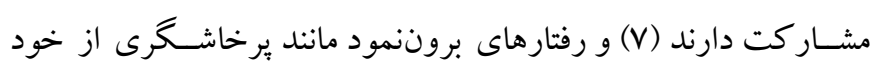

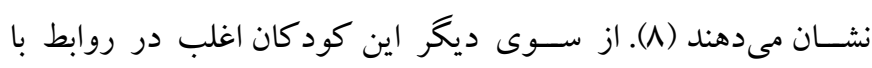

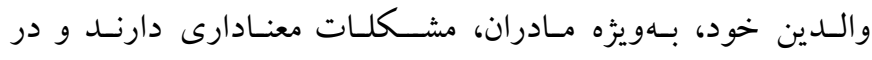

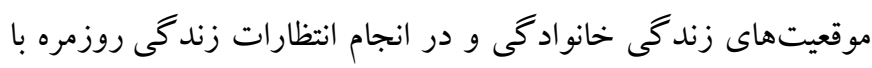

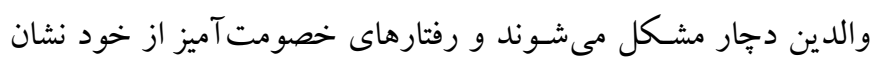

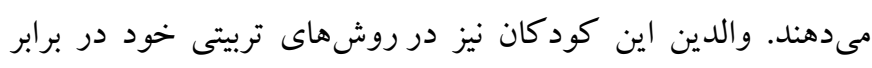

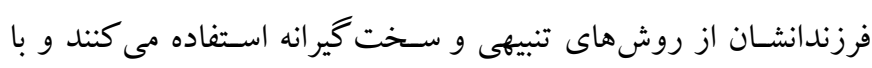


روش الف) طرح هزوهش و شـــ كت كنند كان: يُزوهش حاضـر يك مطالعه

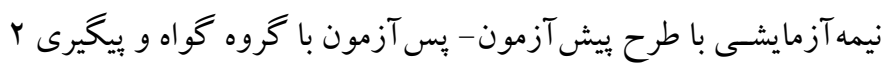

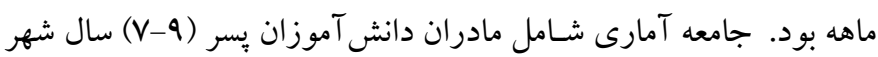

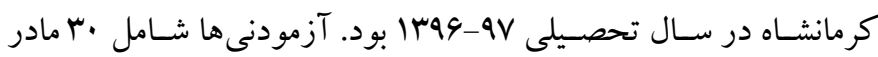

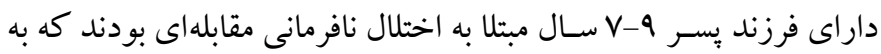

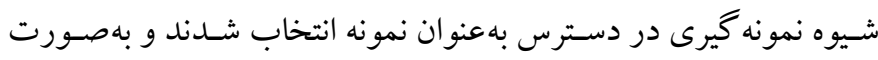

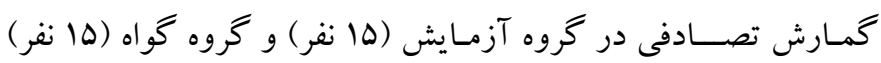
جايدهى شــند. انتخاب نمونه در جنس مذكر به علت شـيوع بيشـتر اين

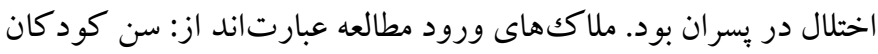

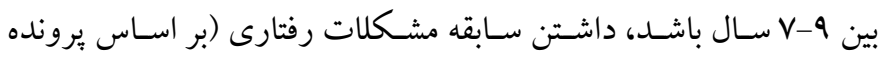

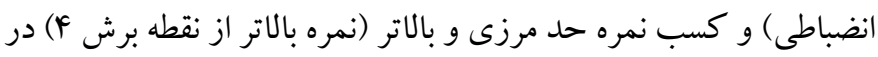

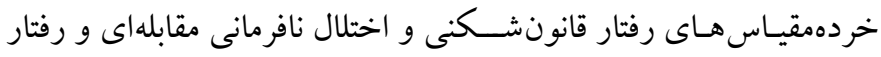

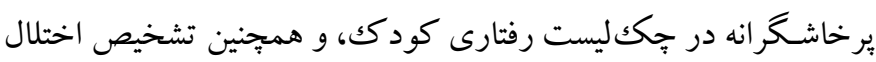
نـافرمانى مقابلهاى در مقياس علائم مرضسى كود كان. ملاككهاى خروج

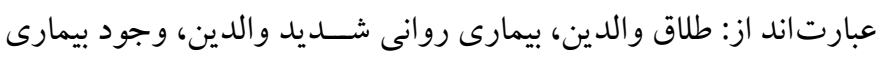

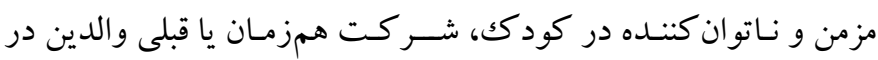
دورههاى مشابه روانى - آموزشى، و مصرف داروهاى دود اعصاب و روان.

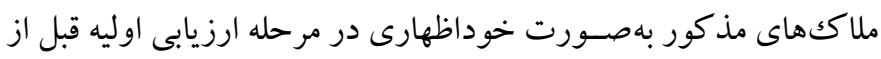

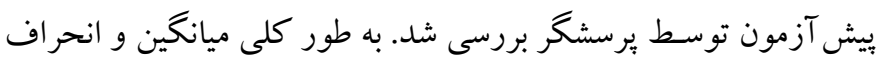

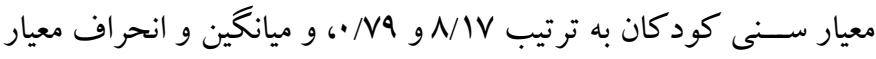

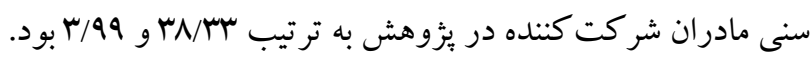
ب) (بزار 1. فهرست رفتارى كودكك !: اين مقياس توسط اخنباخ و رسكورلا (Yr)

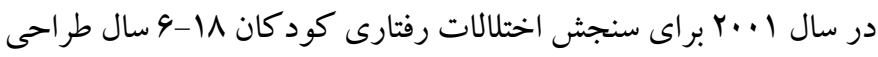

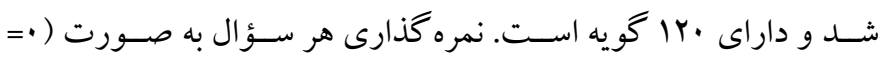

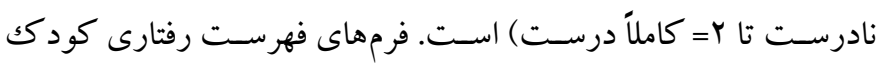

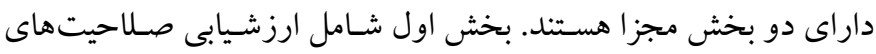
كودك و بخش دوم شـامل برسششهاى مرتبط با اختلالات خاص است.

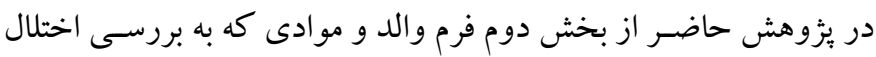

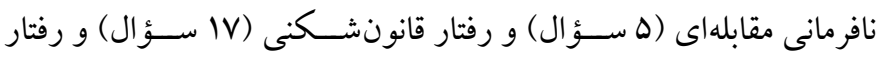

اسـت. همجنين نتايج يُزوهش زينالى، خانجانى، و سهر ابى (1) نشان داد

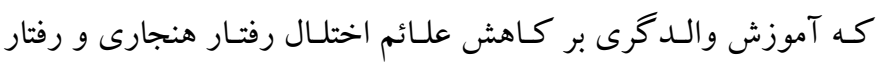
يرخاشخرانه مؤثر بوده است.

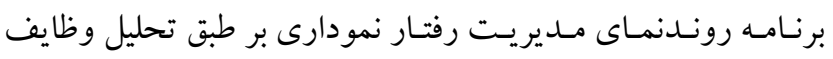

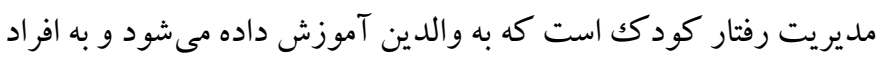
اجازه مى دهد كه تجسم واضحى از مراحل مديريت رفتار كود كك داشته

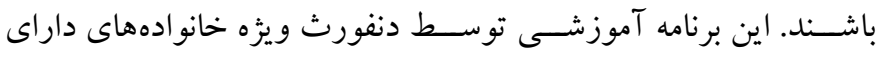

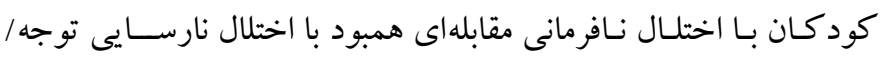

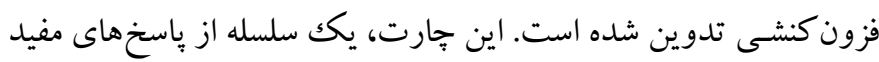

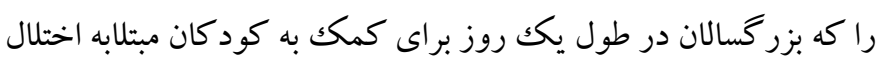

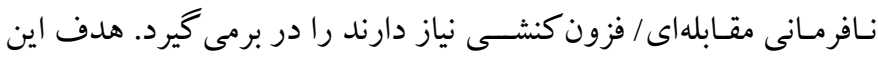
آموزش، توسعه مهارت هاى خاص والدين است كه سبب بهبود رفتارهاى

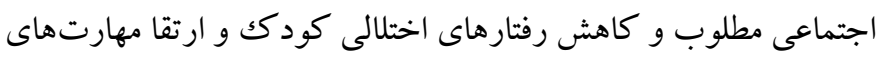
ويزه والدينى است كه باعث تقويت و اصلاح تعامل ها با كود كك مى شود ونس

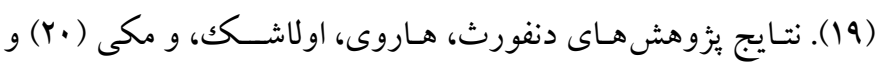

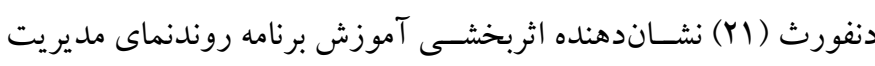
رفتار بر كاهش اختلال فزون كنشى و رفتار تهاجمى كود كان بود.

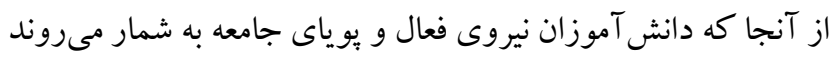

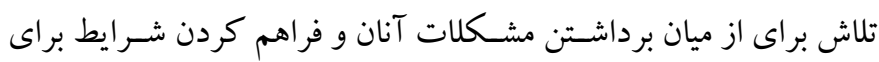

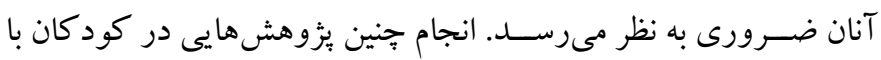

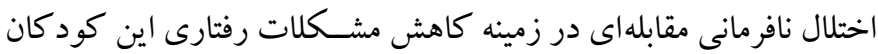

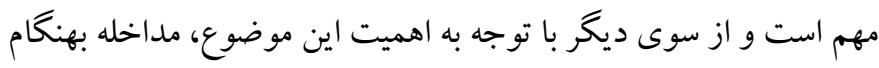

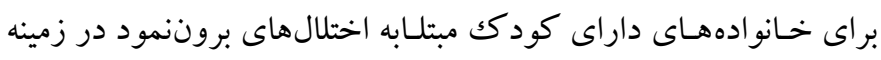
مديريت رفتار فرزندان لازم اسـت تا با تأكيد بيشتر در اين زمينه از حادتر دابه

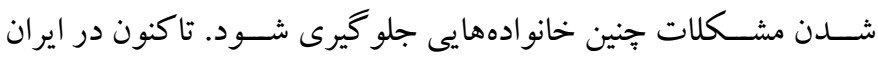

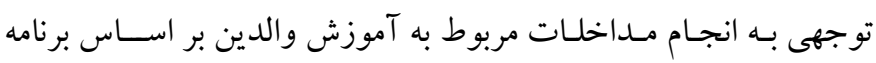
روندنماى مديريت رفتار و بررسسى اثربخشسى آن در حيطههاى مختلف

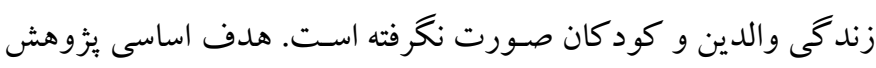

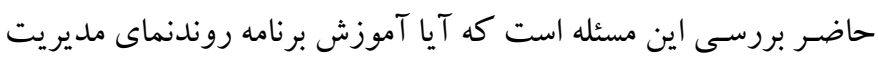

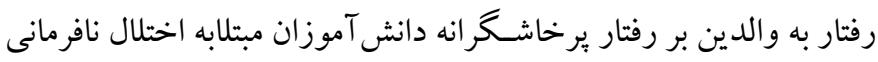

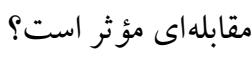


اسـت. ســؤالهاى مربوط به اختلال نافرمانى مقابلهاى در اين برسـشــامه سؤالهاى 19 تا و ب را به خود اختصـاص داده اسـت. اين فهرسـت به دو روش متفاوت نمره كذارى مىشود: () روش برش غربال كننده، Y) روش نمره گذارى شـدت. در اين يزوهش از روش نمره كذارى شـدت استفاده شـــ. در يثزوهش كر ايسـون و كارلسـون (YD) ضـريب اعتبار نمره كل و

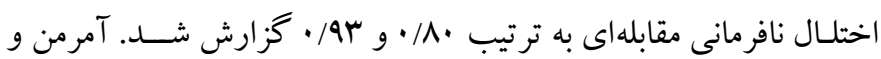
همكـاران (1991) روايى ســازه اين مقيـاس را بررسـى كردنــ و نتايج يزٔوهش آنها نشـان داد كه نمرات برسـشـنامه مرضسى كود كان فرم ويزه والدين با يرسـشـنامه شـخصسيتى كود كان همبستكى مثبتى دارد (Y) (Y). در ايران نيز محمــداســـــاعيل و على بور اعتبـار نمره كـل و مقيـاس اختلال نافرمانى مقابلهاى را به ترتيب 1/| • و Y9/ • گزارش كردند، علاوه بر اين در اين يزٔوهش روايى محتوايى اين آزمون توســط ارزيـابىهـا و نظر متخصصان (روانيزشكان) تأييد شده است (YV). ج)برنامه مداخلهاى: در اين يثوهش برنامه روندنماى مديريت رفتار بر اسـاس راهنماى دنفورث (9 1) به مدت 1 جلسـه ·9 دقيقهاى بهصسورت كروهى و يكك جلسه در هفته براى مادران گروه آزمايش اجرا شد. در جدول ا محتواى جلسات آموزشى بهاختصار ارائه شده است.
برخاشخر انه ( •r سؤ ال) مى يردازد، استفاده شد. در اين فرم كود كانى كه نمره بالاتر از نقطه برش (نمره \&) را كسـب مى كنند، دجار مشكل هستند. آخنباخ و رسـكورلا (Yr) ضـريب اعتبار اين سـياهه رادر دامنه 9ه/ • تا

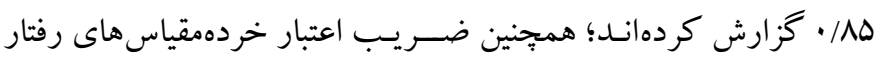
قانونشـكنى، رفتار برخاشـكرى، برون بمود و اختلال نافرمانى مقابلهاى به

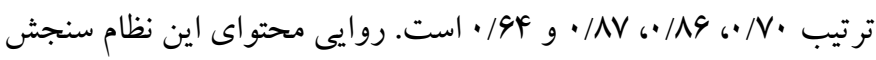
در جهار دهه يُزوهش مورد تأييد قرار گر فته اسـت (YYY). ضسريب اعتبار

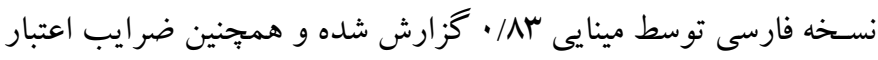

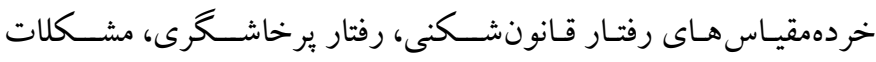

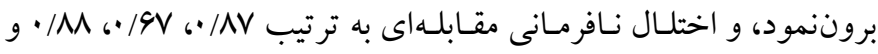

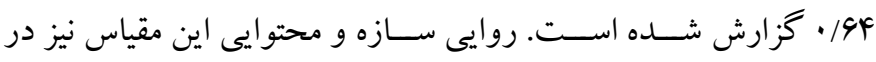
هنجاريابى ايرانى توسط مينايى مورد تأييد قرار گر فته است (سY). r. برسـشـنامه علائم مرضسى كودكان ': اين يرسـشـنامه توسـط كاداو و اسبرايفكين (YF) در سال 199F ابراى شايع ترين اختلالات روانى كود كان rا-ه سـال تدوين شد و شامل دو جِك ليست والدين و معلمان است كه در يُزوهش حاضـر از فرم والد آن استفاده شد. فرم والد شامل r الا سؤال همر اه با طيف ليكرت F درجهاى (هر گز، گاهى، اغلب، و بيشـتر اوقات) اسـت كـه داراى دامنـه از · تا مدر زيرمقياس اختلال نافرمانى مقابلهاى

جدول ا: خلاصه محتواى برنامه روندنماى مديريت رفتار، دنفورث (7 +. †)

\begin{tabular}{|c|c|c|c|c|}
\hline زمان و مكان & روش تدريس & اهداف يادكيرى & محتوا & جلسه \\
\hline و 9 دقيقه & آموزش با روش سخنرانى و ارائه & 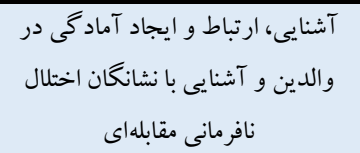 & 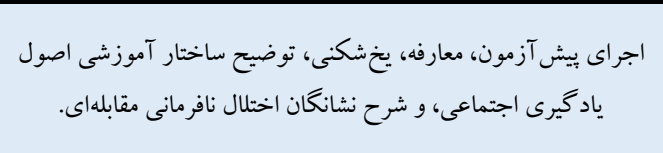 & 1 \\
\hline و 9 دقيقه & آموزش با روش سخنرانى و بحث & 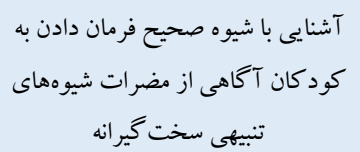 & مرور جلسه قبل، آموزش و تمرين جگگ دنگى فرمانهاى عملى يا & r \\
\hline 9 9 دقيقه & تمرين عملى و استفاده از اسلايد & 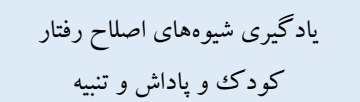 & مرور جلسه قبل، آموزش و تمرين جِكونخى ياداش و توبيخ پاسخهاى & $r$ \\
\hline 9 9 دقيقه & بحث آزاد و تبادل نظر گروهى و & ياد گيرى شيوههاى صحيح تنبيه و & مرور جلسه قبل، آموزش و تمرين نحوه محرومسازى و تهيه فهرستى از & f \\
\hline 9 9 دقيقه & تمرين عملى و استفاده از اسلايد & رفاد گيرى و تمرين روشهاى اصلاح & 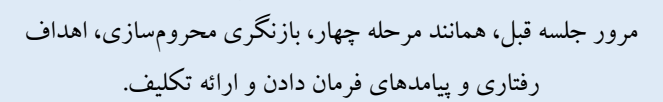 & $\Delta$ \\
\hline
\end{tabular}

1. Child Symptom Inventory- 4 (CSI- 4) 


\begin{tabular}{|c|c|c|c|c|}
\hline •q دقيقه & بحث آزادو تبادل نظر گروهى و & مرور گامها و تمرين روشهاى اصلاح & مرور جلسه قبل، بازنخرى مشكلات خاص و تمامى كامها و ارائه تكليف. & $v, q$ \\
\hline •q دقيقه & بحث آزادو تبادل نظر گروهى و & 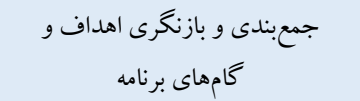 & بازنغرى اصول ياد گيرى اجتماعى، و بازنگرى مجدد تمامى گامها، & $\wedge$ \\
\hline
\end{tabular}

رضــايت نامه كتبى را امضـــا كردند. براى رعايت موازين اخلاقى يس از اتمام مراحل بثزوهش، برنامه روندنماى ملديريت رفتار در ب جلسه به گروه كواه نيز آموزش داده شـد. همجنين ساير ملاحظات اخلاقى مانند محر مانه مـاندن اطلاعات، رعايت اصـل رازدارى، و اخذ رضـايت كتبى در اين مطالعه رعايت شد. دادهها با استفاده روش طرح تحليل واريانس مختلط با اندازه گيرى مكرر تحليل شد.

\section{بافتهاف}

در جدول Y شـاخص هاى توصسيفى رفتار برخاشـكر انه، شـامل ميانخين و

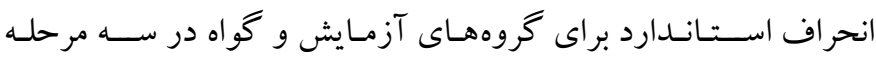

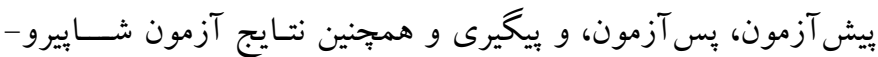
ويلك براى بررسى نرمال بودن توزيع دادهها كزارش شدهاند. با توجه به مـعــىدار نبودن آمـاره اين آزمون مى توان كفـت كـه توزيع رفتـار يرخاشگر انه نرمال است.
د) روش اجرا: بعد از گرفتن مجوزهاى للازم از آموزشوبرورش شــهـ كرمانشـاه، ابتدا از بين مدارس دولتى اين شهر دو مدرسـه ابتدايى بسر انه بهصـورت غير تصـادفى در دسـترس انتخاب شـدند و با توجه به سـابقه مشكلات رفتارى دانش آموزان در يرونده انضباطى مدارس، از .ا نفر از مادران دعوت شد و نشست توجيهى براى آنها در مدرسه بر گزار شد و با ارائه بيرسـشــنامه فهرسـت رفتارى كود كان و يرســـــامه علائم مرضـى كود كان به مادران، كود كان مبتلابه اختلال نافرمانى مقابلهاى غربال شدند. از بين •ه نفر واجد شـرايط، تعداد ·ب نفر از مادران انتخاب و بهصـورت كمارش تصادفى در دو گروه آزمايش و گواه قرار كرفتند. ابتدا از افراد، يبش آزمون گر فته شـد، سيس برنامه روندنماى مديريت رفتار در ^ جلسه كروهى، هفتـهاى يكك جلســه براى گروه آزمايش در ســالن جلســات

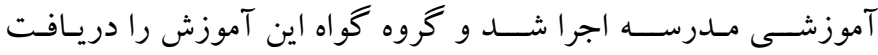
نمى كردند. ســبس مجدداً هر دو گرووه در يس آزمون مورد ارزيابى قرار

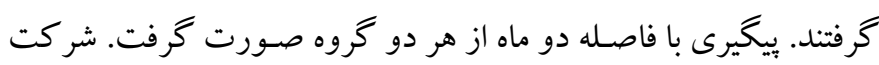
در يزٔوهش كاملاً اختيارى بود و شـر كت كنند كان قبل از اجراى بزّوهش

جدول ب: شاخصهاى توصيفى رفتار يرخاشكَ انه براى كروه آزمايش و كواه در سه مرحله ييش آزمون، يسآزمون، و ييكيرى

\begin{tabular}{|c|c|c|c|c|c|}
\hline سطح معنى دارى & آزمون شاييرو-ويلكك & انحر اف استاندارد & ميانكين & كروه & مرحله \\
\hline -/Ar &.$/ 99$ & $\Delta / / \Lambda$ & $V \Delta / V \pi$ & آزمايش & \multirow{2}{*}{ بيش آزمون } \\
\hline$\cdot /$ / & . /9 & $9 / \mathrm{TV}$ & VT/AG & كو اه & \\
\hline .1 .9 & $\cdot / M$ & $\mathrm{~V} / \mathrm{VV}$ & $90 / 94$ & آزمايش & \multirow{2}{*}{ يس آزمون } \\
\hline$\cdot / \mathrm{V} \Delta$ &.$/ 99$ & $\Delta / F T$ & $\sqrt{9 / 94}$ & كواه & \\
\hline$\cdot / 4 \wedge$ & $\cdot / 9 F$ & $\Lambda / r V$ & $94 / 1 \pi$ & آزمايش & \multirow{2}{*}{ ييخيرى } \\
\hline . & $\cdot / 9 r$ & $9 / N r$ & $V G / Y q$ & كواه & \\
\hline
\end{tabular}

عضويت گروهى بود؛؛ لذا طرح مورد استفاده طرح درون- بين آزمودنى اسـت. در جدول بنتايج آزمون موجلى جهت بررسى كرويت متغيرهاى يزّوهش كزارش شده است.
براى بررسى تأثير برنامه روندنماى مديريت رفتار بر رفتار برخاشخر انه كود كان داراى اختلال نافرمانى مقابلهاى از تحليل واريانس با اندازه كيرى مكرر استفاده شده است. در اين يزوهش يكك عامل درون آزمودنى وجود داشت كه زمان اندازه گيرى رفتار يرخاشگر انه در سه مرحله بيش آزمون، يس آزمون، و بيكيرى بود و يكك عامل بين آزمودنى وجود داشت كه آن 
جدول ץ: نتايج آزمون موجلى رفتار يرخاشكرانه

\begin{tabular}{|c|c|c|c|c|c|}
\hline إيسيلون هاين فلت & ايسيلون ترين هاوس تيسر & سطح معنى دارى & درجه آزادى & مجذور خى & W موجلى W \\
\hline.$/ 91$ & $\cdot / \wedge 9$ &.$/ \mathrm{IV}$ & $r$ & $r / F \wedge$ & $\cdot / \mathrm{AV}$ \\
\hline
\end{tabular}

بنـابراين بـا در نظر گرفتن مفروضسهـ كرويـت در جـدول \& نتايج آزمون

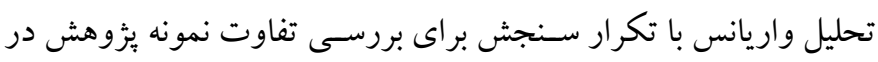

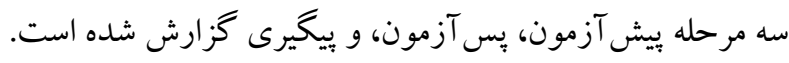

نتـايج جـدول ب نشــان مى دهــ كـه آمـاره W مو جلى براى رفتـار

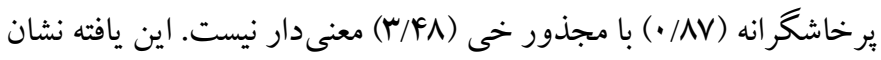

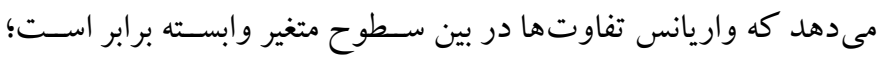

جدول ع: نتايج آزمون تحليل واريانس اندازهكيرى مكرر رفتار يرخاشكرانه

\begin{tabular}{|c|c|c|c|c|c|}
\hline مجذور اتا & سطح معنى دارى & آماره f & درجه آزادى & ميانكين مجذورات & منابع تغييرات \\
\hline \multirow[t]{2}{*}{$\cdot / T V$} & 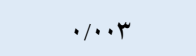 & $1 \cdot / \pi q$ & 1 & $11 \cdot r / \Delta$ & كروه - اه \\
\hline & & & ru & 1.91 .4 & خطا \\
\hline$\cdot / r 9$ &.$/ .1$ & $11 / r$ & r & $|v r /|$ & مراحل \\
\hline \multirow[t]{2}{*}{.$/ 81$} &.$/ .1$ & $r Q / Y r$ & r & $F F \Delta / q$. & تعامل مراحل با كُروه \\
\hline & & & 10 & $10 / Y 9$ & خطط \\
\hline
\end{tabular}

كروهى نشــان مىدهد، عضـويت گروهى YV درصـــ از تغييرات متغير

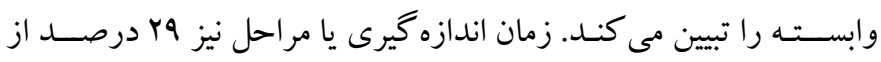

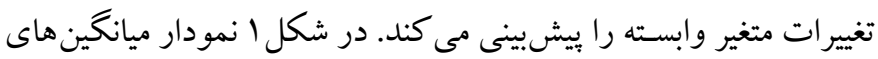

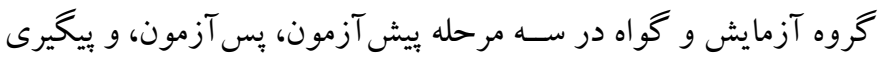
نشان داده شده است.
همانطور كه در جدول F نشـان داده شـده اسـت، ميزان F اثر تعامل

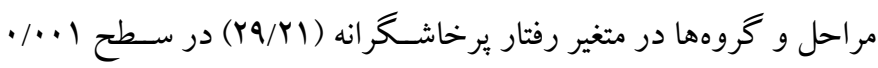

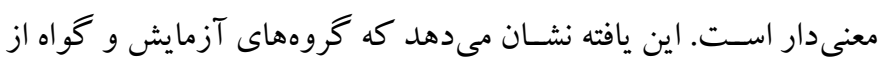

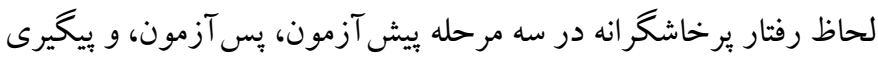

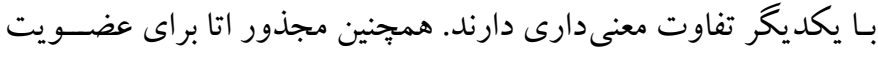

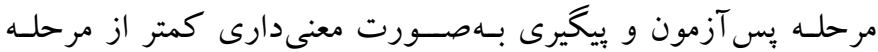

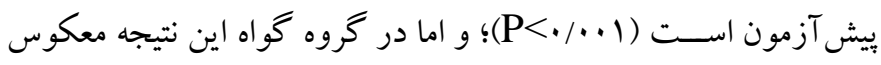

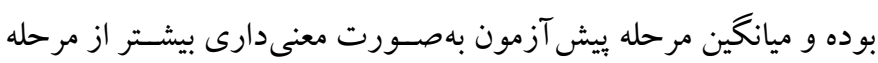

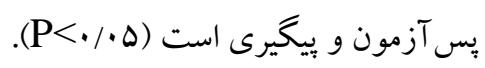

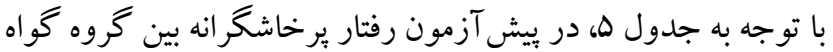

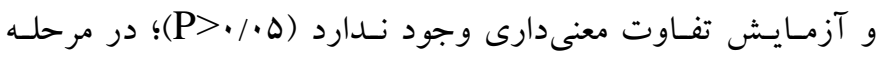

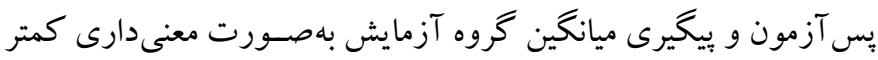

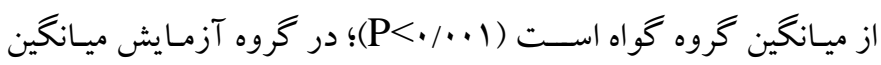




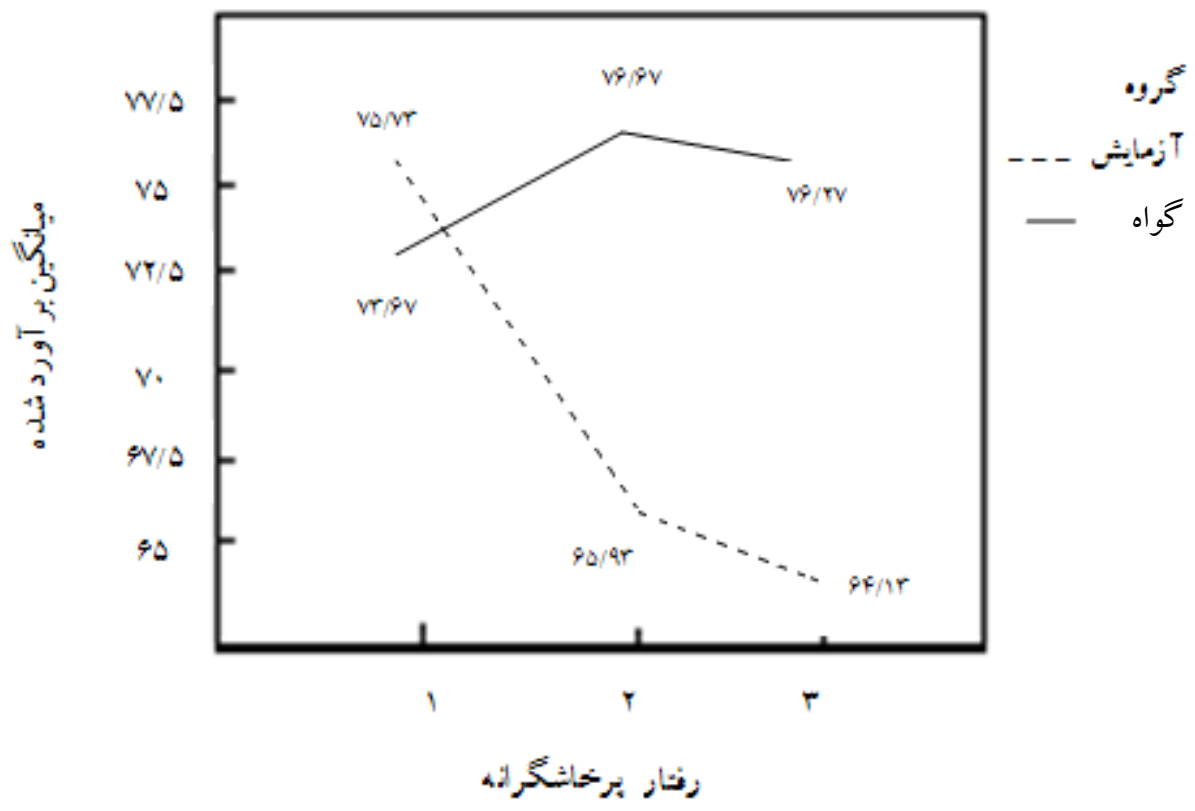

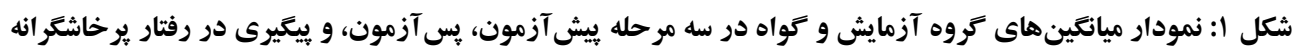

طبيعى خانو اده فراكرفته مىشـوند، بنابراين آموزش افرادى كه بيشـترين

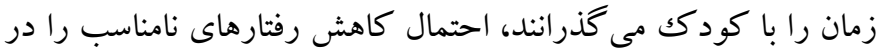

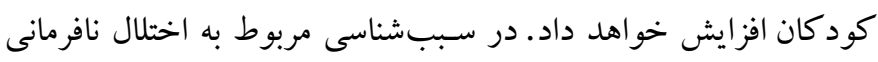
مقابلهاى، مهم ترين عامل، واكنش شـديد والدين نسـبت به رفتارهاى

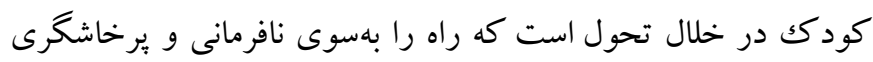

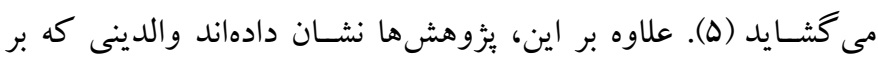

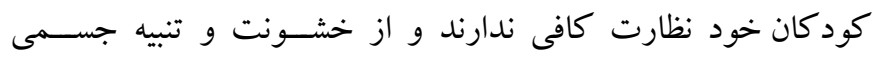

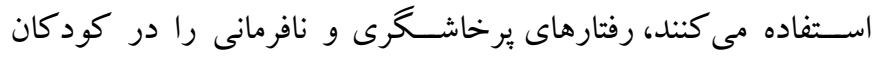

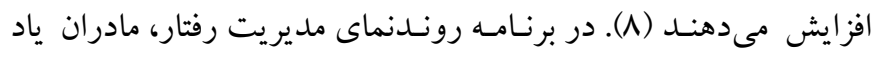

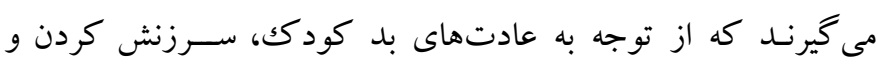

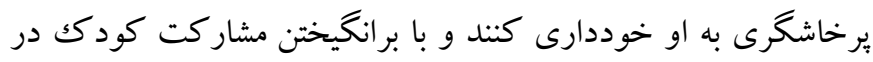

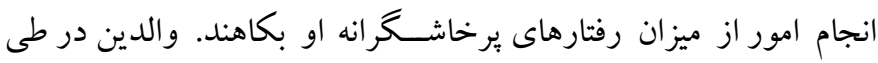
جلسات تحت تأثير مهارتهاى توجهى مهم از قبيل كوش دادن و توجه

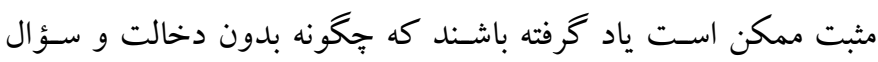

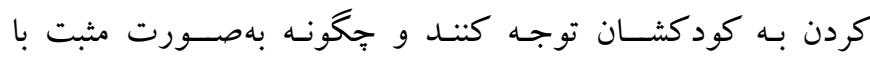
اظهارنظرهاى خود رفتارهاى مطلوبى را كه مىخواهند كود كشـان آنها

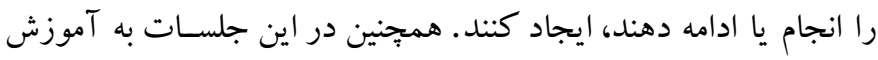

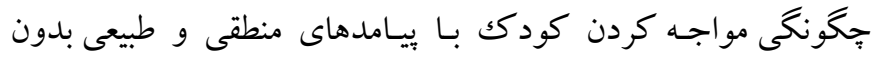

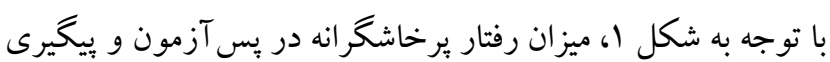

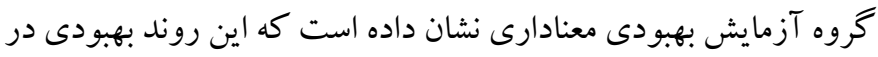

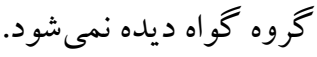

\section{بحث و نتيجه كيرى} هدف از انجام يزوهش حاضر بررسى اثربخشى آموزش برنامه روندنماى

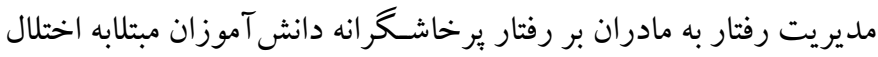

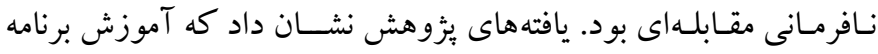

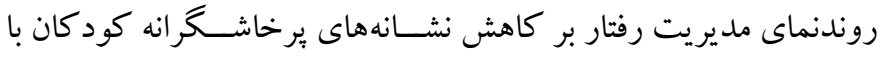

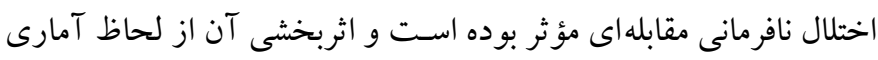

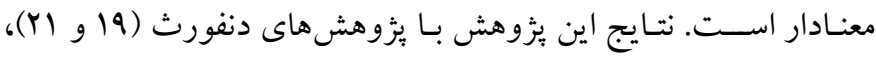

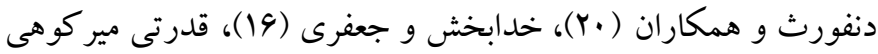

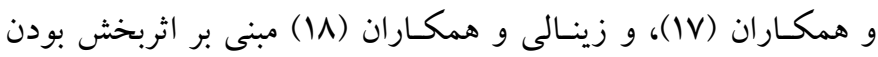

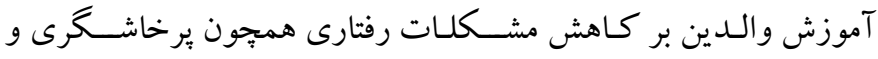
اختلالات برون انمود در كود كان، همسو است.

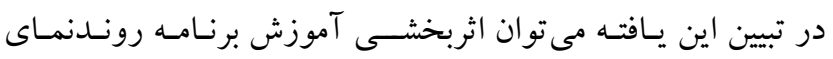

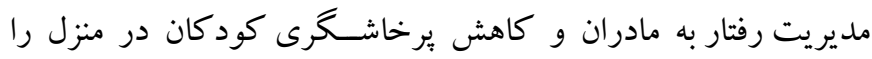
ناشى از اين دلايل دانست: بسيارى از مشكلات بروننمود در محيط 
بايد توجه داشــت كه بثوهش حاضــر با محدوديتهايى نيز مواجه بوده اسـت كه در هنگام تعميم نتايج به دسـت آمده بايد با احتياط عمل كرد. از جملـه اين محسدوديـت هـا مى توان بـه اين موارد اشــاره كرد: 1. اضـطر اب جدايى والدين، سـطح دلبسـتكى والدين، و مشـكلات رفتارى درمان نشده در والدين كود كان مورد بررسى و كنترل قرار نخرفته است، Y. عــدم همـاهنكى كـامـل مســـو لين مدارس مانع از اجراى نمونه كيرى تصــادفى در تمامى اجراى بثروهش شـــده اســت، س. ملاككهاى خروج يثزوهش از جمله وضسعيت روانى والدين بهصسورت خوداظهارى بررسى شـــد و افر اد مورد مطالعه تحت معاينه متخصـصص قرار نخرفتند، و F. اين برنامه فقط در نمونهاى از يسران اجرا شد و اثربخشى آن بر روى فرزندان دختر بررسى نشـد. بلدين ترتيب بيشـنهاد مى شـود در بئوهش هاى بعدى اين برنامه در نمونهاى از دختران و يسـران بهصورت مجزا بررسى شود و تفاوت هاى جنسيتى در اثربخشى اين برنامه روشن شود. همجنين استفاده

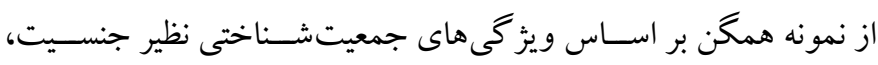
يـايخـاه اجتماعى و اقتصــادى، و يا اســتفاده از روش نمونه كيرى كاملاً تصادفى، مى تواند بر دقت نتايج بيفزايد. بر اساس نتايج به دست آمده در سـطح به كار بسـته بيشـنهاد مى شـود برنامه مداخلهاى حاضر هم در سطح كلينيكى و هم در ســطح آموزش هـاى عمومى در مـدارس تحـت قالب آموزش والدين به كار كرفته شود.

تشكر و قدردانى: اين مقاله بهصورت مستقل اجرا شده و مجوز اجراى آن بر روى افراد نمونه از سوى سازمان آموزش يرورش شهر كرمانشاه با شماره مجوز

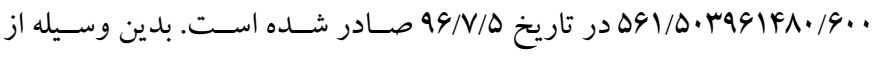
تمامى افراد مساعدت كننده در فرايند بزوهش تشكر و قدردانى مىشود.

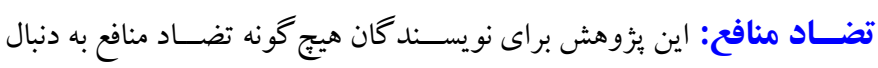
نداشته است.
اعمال روشهاى تنبيهى سخت گير انه و به كار نبردن سرزنش بيشازحد و يرخاشكرى در برابر مشكلات رفتارى كود كان برداخته شد. در جلسـات اول، جهت بالا بردن ســطح آكاهى مادران به شـناخت اختلـال نافرمانى مقابلهاى و علائم آن برداخته شــــ و اين كام مؤثرى در آكَاه شــدن مـادران از نيـازهـاى كود كـان داراى اين اختلال بود. با اين آكَاهى آنهـا فرزنـد خود را بهتر دركك مى كنتـد و در مقـابـل رفتار آنها انعطاف يذيرى بيشترى خواهد داشت و تا حد امكان با ملايمت و صبورى بـا كودكـان برخورد خواهنــ كرد و بر اين اســاس در طى آموزش اين روش، والدين احســاس آرامش بيشــترى مى كنند و همجِين احســاس مى كنند كه مديريت بيشسترى بر روى امور دارند. يكى از اصسولى كه در برنامه آموزش والدين بر روى آن تأكيد بسيار مىشود ايجاد رابطه گرم و صسميمى بين والد و كود كك اسـت كه با استفاده از تكنيككهاى مختلف (مانند صرف زمان خاص و كفتخوى صميمانه و محبت جسمانى) به اجرا در مى آيد و مادران در طول دوره آموزشى، احساس صميميت بيشترى به كود كـانشــان بيــا مى كنتـد. برنـامـههاى آموزش والدين در محيطهاى كروهى براى خانو ادههايى كه كود كانى با مشكلات رفتارى مخرب بسيار حادى دارند، مزاياى زيادى دارد و مؤثرتر از جلسات فردى است. در اين روش فنون شكل دهى رفتار بر اساس اصول ياد گيرى اجتماعى به والدين آموزش داده مىشـود. والدين ياد مى گيرند كه بيشـايندها و بسـايندها را

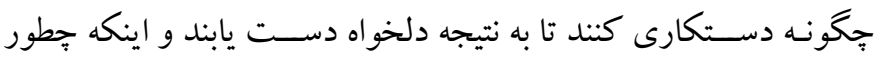
رفتـارهـاى كود كان را نظارت كنند، جّكونه يّاداش هاى معينى بدهند و با توجه به رفتارهاى مثبت مشـكلات را كاهش دهند، و كمتر از تنبيه بلنى استفاده كنند. اين فنون و مزاياى روش آموزش برنامه روندنماى مديريت

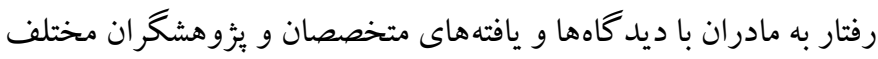
(مانند · Y و آ) مورد تأييد قرار كرفته است. 


\section{References}

1. Azizi A, Karimipoor BA, Rahmani S, Veisi F. Comparing the efficacy of child-parent relationship therapy (CPRT) and family-focused therapy (FFT) on function of families with children with oppositional defiant disorder (ODD). Quarterly Journal of Child Mental Health. 2016; 3(2): 9-20. [Persian]. [Link]

2. Blumberg BM. Oppositional defiant disorder: a case report. Journal of Psychiatry and Psychiatric Disorders. 2017; 1(4): 199-211. [Link]

3. Farzadi F, Behroozy N, Faramarzi H. Comparison of theory of mind, attention maintenance and sympathy in students with and without oppositional defiant disorder. Quarterly Journal of Child Mental Health. 2017; 3(4): 70-79. [Persian]. [Link]

4. Urquiza AJ, Timmer SG. Parent-child interaction therapy: Enhancing parent-child relationships. Psychosocial Intervention. 2012; 21(2): 145-156. [Link]

5. Bjørseth Å, Wichstrøm L. Effectiveness of parent-child interaction therapy (PCIT) in the treatment of young children's behavior problems. A randomized controlled study. PLOS ONE. 2016; 11(9): e0159845. [Link]

6. Vahia VN. Diagnostic and statistical manual of mental disorders 5: A quick glance. Indian J Psychiatry. 2013; 55(3): 220. [Link]

7. Bussing R, Zima BT, Mason DM, Meyer JM, White K, Garvan CW. ADHD knowledge, perceptions, and information sources: perspectives from a community sample of adolescents and their parents. J Adolesc Health. 2012; 51(6): 593-600. [Link]

8. Burke JD, Rowe R, Boylan K. Functional outcomes of child and adolescent ODD symptoms in young adult men. J Child Psychol Psychiatry. 2014; 55(3): 264272. [Link]

9. Kledzik AM, Thorne MC, Prasad V, Hayes KH, Hines L. Challenges in treating oppositional defiant disorder in a pediatric medical setting: a case study. $\mathrm{J}$ Pediatr Nurs. 2012; 27(5): 557-562. [Link]

10. Salimi Souderjani M, Yousefi Z. The effectiveness of parenting styles training based on acceptance and commitment therapy (ACT) to mothers on decreasing separation anxiety and oppositional defiant disorder of children. Quarterly Journal of Child Mental Health. 2017; 4(2): 104-116. [Persian]. [Link]

11. Amiri M, Movallali G, Nesayan A, Hejazi M, Asadi Gandomani R. Effect of behavior management training for mothers with children having ODD symptoms. Archives of Rehabilitation. 2017; 18(2): 84-97. [Persian]. [Link]

12. Khabbaz M, Alizadeh H, Delavar A, Ebrahimi Ghavam S, Rostami R, Behjati Z. The effectiveness of social interest fostering program (mother-child) on psychological basic needs satisfaction in students with oppositional defiant disorder. Journal of Applied Psychological Research. 2016; 6(4): 15-30. [Persian]. [Link]

13. Self-Brown S, Frederick K, Binder S, Whitaker D, Lutzker J, Edwards A, et al. Examining the need for cultural adaptations to an evidence-based parent training program targeting the prevention of child maltreatment. Children and Youth Services Review. 2011; 33(7): 1166-1172. [Link]

14. Forehand R, Parent J, Sonuga-Barke E, Peisch VD, Long N, Abikoff HB. Which type of parent training works best for preschoolers with comorbid ADHD and ODD? A secondary analysis of a randomized controlled trial comparing generic and specialized programs. J Abnorm Child Psychol. 2016; 44(8): 1503-1513. [Link]

15. Yaghoobi A, Mahdavi A, Mohamadzade S. The metaanalysis of the effectiveness of psychological and educational interventions on the reduction of symptoms of oppositional defiant disorder. Quarterly Journal of Child Mental Health. 2018; 5(2): 164-173. [Persian]. [Link]

16. Khodabakhsh R, Jafari M. Exploring the efficacy of parental training with Adlerian approach on coping styles of mothers of children with oppositional defiant disorder \& on reduction Of ODD symptoms. Journal of Psychological Studies. 2014; 10(1): 7-30. [Persian]. [Link]

17. Ghodrati M, Sharifi Daramadi P, Abdollahi G. The effect of parental management training base on cognitive- behavior therapy on children with oppositional defiant disorder. Psychology of Exceptional Individuals. 2015; 5(20): 109-123. [Persian]. [Link]

18. Zeinali SH, Khanjani Z, Sohrabi F. Investigate the efficacy of parenting skill in reducing adolescent conduct disorder and aggression. Journal of Health. 2016; 6(5): 565-574. [Persian]. [Link]

19. Danforth JS. Parent training for families of children with comorbid ADHD and ODD. Int J Behav Consult Ther. 2006; 2(1): 45-64. [Link]

20. Danforth JS, Harvey E, Ulaszek WR, McKee TE. The outcome of group parent training for families of children with attention-deficit hyperactivity disorder 
and defiant/aggressive behavior. J Behav Ther Exp Psychiatry. 2006; 37(3): 188-205. [Link]

21. Danforth JS. The outcome of parent training using the behavior management flow chart with mothers and their children with oppositional defiant disorder and attention-deficit hyperactivity disorder. Behav Modif. 1998; 22(4): 443-473. [Link]

22. Achenbach TM, Rescorla L. Manual for the ASEBA school-age forms \& profiles : an integrated system of multi-informant assessment. Burlington, VT: ASEBA; 2001. [Link]

23. Minaee A. Adaptation and standardization of child behavior checklist, youth self-report, and teacher's report forms. Journal of Exceptional Children. 2006; 6(1): 529-558. [Persian] .[Link]
24. Gadow KD, Sparfkin J. Child symptom inventories manual. Story brook, NY: Checkmate plus; 1994, pp: 21-35.

25. Grayson P, Carlson GA. The utility of a DSM-III-Rbased checklist in screening child psychiatric patients. J Am Acad Child Adolesc Psychiatry. 1991; 30(4): 669-673. [Link]

26. Ammerman RT, Kane VR, Slomka GT, Reigel DH, Franzen MD, Gadow KD. Psychiatric symptomatology and family functioning in children and adolescents with Spina bifida. J Clin Psychol Med Settings. 1998; 5(4): 449-465. [Link]

27. Mohamadesmaiel E, Alipour A. A preliminary study on the reliability, validity and cut off points of the disorders of children symptom inventory-4 (CSI-4). Journal of Exceptional Children. 2002; 2(3): 239-254. [Persian]. [Link] 